\title{
CONSTRUCTION AND VALIDATION OF SCALE OF BARRIERS TO PARTICIPATION IN EDUCATION
}

\author{
[KONSTRUKCIJA IN VALIDACIJA LESTVICE OVIR PRI \\ ODLOCANJU ZA IZOBRAZEVANJE (LOI)]
}

\author{
Nina Krmac - Tina Stemberger
}

\section{doi: 10.18355/PG.2017.6.2.5}

\begin{abstract}
The study aimed to construct and validate the Scale of Barriers to Participation in Education. The bases for item generation were various theoretic and empirical concepts. In order to test validity and internal consistency of the scale, item analysis, exploratory and confirmatory factor analysis and Cronbach's $\alpha$ were used. Based on the sample of 158 adults, the factor analysis with the principal components extracted 3 components: Time and logistics barriers, (ii) Personal barriers and (iii) Perceived Effort. Results indicate Scale of Barriers to Participation in Education to be a valid and a reliable instrument for measuring barriers in entering education.
\end{abstract}

\section{Key words}

barriers for participation in education, scale, validation, factor analysis

\section{Povzetek}

Cilj predstavljene študije je bil oblikovati in validirati Lestvico ovir pri odločanju za izobraževanje (LOI), pri čemer so bile postavke za lestvico oblikovane na podlagi obstoječih teoretičnih konceptov ovir. Za ugotavljanje veljavnosti sta bili uporabljeni konfirmatorna in ekploratorna fakotrska analiza, za ugotavljanje notranje konsistentnosti pa je bil uporabljen Cronbachov alfa koeficient. Na vzorcu 158 odraslih je faktorska analiza $\mathrm{z}$ metodo glavnih komponent izločila 3 komponente, in sicer: (i) Časovno logistične ovire (ii) Personalne ovire in (iii) Doživljanje lastnega napora. Rezultati kažejo, da je oblikovana Lestvica ovir pri odločanju za izobraževanje veljaven in zanesljiv instrument in se ga lahko uporabi za nadaljnje raziskovanje tega pojava.

\section{Ključne besede}

ovire pri izobraževanju, lestvica, validacija, faktorska analiza

\section{Uvod}

Navkljub dejstvu, da ima Slovenija v skupini postsocialističnih držav najvišjo stopnjo participacije odraslih v izobraževanju (Roosma in Saar, 2011), najnovejši izsledki raziskav kažejo, da so odrasli v Sloveniji v povprečju manj besedilno in matematično spretni v primerjavi z vrstniki iz ostali držav OECD (OECD 2016), kar nakazuje potrebo po večji in bolj intenzivni vpetosti odraslih $\mathrm{V}$ različne oblike izobraževanja. Da bi $\mathrm{v}$ tovrstna

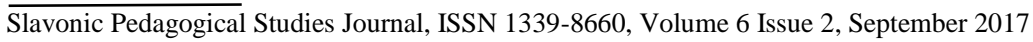


izobraževanja vključili čim več udeležencev ciljne skupine in predvsem aktivirali tiste, ki se doslej niso vključevali ali so se vključevali v manjši meri, moramo najprej ugotoviti, katere so tiste ovire, ki najbolj preprečujejo vstop v izobraževanje.

Friebe in Schmidt-Hertha (2013) poudarjata, da je zavedanje ovir, ki v večini primerov poslabšajo vključevanje odraslih $\mathrm{v}$ izobraževanje, dragoceno tako za načrtovalce izobraževanih vsebin kot tudi za predavatelje. Vsakršno raziskovanje zahteva tudi razvoj in validacijo ustreznih merskih instrumentov, ki raziskovalcem omogočajo pridobivanje veljavnih in zanesljivih rezultatov, kar velja tudi za področje ovir pri vstopanju $\mathrm{v}$ izobraževanje. Prav zato v prispevku predstavljamo rezultate študije, katere cilj je bil, na osnovi tako teoretičnih konceptov, kot tudi prejšnjih empiričnih konstruktov, oblikovati instrument, ki bi omogočal merjenje ovir $\mathrm{v}$ slovenskem socio-kulturno-političnem kontekstu.

\section{Teoretična izhodišča}

Oviro razumemo kot prepreko pri doseganju zastavljenega cilja, pri čemer je za lažje razumevanje in odpravljanje ovir dobro poznati njihov izvor, kakor tudi uvrstitev posamezne ovire $\mathrm{v}$ skupine s sorodnimi ovirami. Na področju vključevanja odraslih v izobraževanje se pojavljajo različne klasifikacije ovir. Prvo klasifikacijo ovir pri odločanju za izobraževanje sta oblikovala Johnstone in Rivera (1965), ki sta ovire klasificirala na situacijske in dispozicijske. Skupini je sestavljalo 10 potencialnih ovir. Cross (1981) je omenjeno klasifikacijo dopolnila še s skupino institucionalnih ovir ter tako predstavila danes zelo uveljavljeno tripartitno delitev, tj. (i) situacijske ovire, (ii) institucionalne ovire in (iii) dispozicijske ovire.

Situacijske ovire izhajajo iz lastnega položaja v posameznikovem trenutnem življenju. Kažejo se kot pomanjkanje časa zaradi domačih in delovnih obveznosti (Cross, 1981; European commission, 2005) pa tudi kot pomanjkanje denarja, oddaljenost kraja izobraževanja od kraja bivanja, zdravstveni razlogi (European commission, 2005). Johnstone in Rivera (1965) te ovire opredeljujeta tudi kot zunanje ovire.

Radovan (2012a) je v okviru te skupine ovir posebno izpostavil oviri pomanjkanje časa in predrago izobraževanje, saj sta prav ti dve oviri največkrat ključni pri odločanju za izobraževanje. Ob tem opozarja (prav tam) na potrebno previdnost pri naštevanju ovir, saj lahko pride do pristranskosti in navajanja le tistih dejavnikov, ki so za našo izobraževalno nedejavnost, družbeno spremenljivi (prav tam).

Podobno je izpostavil že McGivney (1990), ki je poročal, da ljudje s povečanim prostim časom niso bolj vstopali v izobraževanje, pač pa so več gledali televizijo, kar kaže na to, da pomanjkanje časa mogoče le ni tako pomembna ovira. Kot je opozoril, je med ljudmi, ki se izobražujejo največ prav tistih, ki so najbolj časovno obremenjeni, na podlagi česa torej sklepa, da prosti čas nima vpliva na udeležbo na izobraževanjih in usposabljanjih. Trdi namreč, da na udeležbo v izobraževanju vplivajo predvsem motivacija, motiv in želja po izobraževanju. To pa je odvisno od osebnosti posameznika 
in posledično tudi kakovosti programov, ki se izvajajo in kako so ti programi med občani promovirani.

Institucionalne ovire vključujejo vse postopke, ki izključujejo ali odvračajo sodelovanje delovnih odraslih v izobraževalne dejavnosti. To so predvsem organizacijske ovire, neustrezni študijski programi, neprilagojene organizacije, neustrezni vpisni pogoji, pomoč pri izobraževanju, urnik predavanj, težave z lokacijo in prevozom, pomanjkanje informacij o ponudbi, ipd. (Radovan, 2012a), pa tudi skromna ponudba in slaba kakovost izobraževanja (European Commission, 2005).

Med dispozicijske ovire uvrščamo ovire, ki so povezane $\mathrm{z}$ odnosom, samoodločbo in dojemanjem o sebi. Povezujejo se $\mathrm{s}$ psihosocialnimi značilnostmi posameznika. To so na primer samopodoba, stališča, motivacija in sposobnosti. Kažejo se denimo v tem, da mnogi starejši državljani menijo, da so prestari za učenje, odrasli s slabo izobraževalno »podlago« pogosto nimajo interesa za učenje in zaupanje v njihove sposobnosti za učenje. Mnogi se za izobraževanje ne odločijo tudi zaradi slabega učnega uspeha $v$ preteklosti (Cross, 1981) ali slabih izkušenj v času začetnega formalnega izobraževanja (European commission, 2005). Johnstone in Rivera (1965) to skupino ovir označujeta tudi kot notranje ovire.

K modelu tripartitne delitve je bila kasneje dodana še četrta skupina ovir (Darkenwald in Merriam, 1982; European Commission, 2005), in sicer informacijske ovire, ki se nanašajo na pomanjkanje informacij o ponudbi izobraževanja in njegovih koristi (prav tam). Poleg dodane četrte skupine sta Darkenwald in Merriam preimenovala Crossove dispozicijske ovire v psihosocialne ovire (Darkenwald in Merriam, 1982).

Nekoliko drugačno klasifikacijo ovir je oblikoval Beder (1990). V sklopu raziskave, v katero so bili vključeni respondenti, ki niso zaključili srednje šole je na osnovi faktorske analize oblikoval 4 faktorje oz. skupine ovir, in sicer: nizka percepcija potreb, doživljanje lastnega napora, odpor do šole, situacijske ovire.

Nizka percepcija potreb vključuje razmišljanje, da zaključek srednje šole ne bo pripomogel $\mathrm{k}$ izboljšanju življenja, da znanje, ki se ga pridobi v šoli ni uporabno, da srednja šola za odrasle ni dovolj kakovostna, da ponovno šolanje ne doprinese $\mathrm{k}$ boljšemu znanju, da diploma ni potrebna, da v srednji šoli ni veliko ljudi te starosti, da niso dovolj motivirani za ponovni vstop ter da bi izobraževanje vzelo preveč časa.

Doživljanje lastnega napora se nanaša na razmišljanje o predragem izobraževanju, o tem, da se ne počutijo dovolj sposobni za ponovni vstop v šolo, da je šolanje prezahtevno, da bi za to porabili preveč časa, da niso dovolj informirani o srednji šoli za odrasle ter strah pred posmehom prijateljev ob morebitni vrnitvi v šolske klopi.

Odpor do šole se kaže v razmišljanju, da jim šola enostavno ni všeč, da so preveč leni, da bi se vrnili nazaj v šolo ter v izjavah, da niso imeli radi šole in se zato ne želijo vrniti.

Situacijske ovire se, kot tudi že v prejšnjih klasifikacijah (Cross, 1981; Johnstone in Rivera, 1965) kažejo v prepričanju, da nimajo dovolj prostega 
časa, da bi se lahko vrnili nazaj v šolo, da morajo skrbeti za družino ter opravljati službene obveznosti.

Nekoliko novejše delitve so oblikovali Larson in Milana (2006), ki sta uporabili podatke Eurobarometra (2003) ter Malhotra in Shapero (2007).

Larson in Milana (2006) sta opravili faktorsko analizo, ki je temeljila na podatkih raziskave, v katero so bili vključeni respondenti starejši od 16 let. Oblikovali sta 5 faktorjev oz. skupin ovir.

Pomanjkanje časa in/ali energije (službene obveznosti mi vzamejo preveč časa, družinske obveznosti mi vzamejo preveč časa, odreči bi se moral prostemu času);

Negativna stališča do ponovnega vstopa v izobraževanje (prestar sem za izobraževanje, nikoli nisem bil dober za učenje, ne bi se rad vrnil nekam kjer je podobno šoli);

Pomanjkanje razpoložljivih izobraževanj (ni izobraževanj za moje potrebe, ni primernih izobraževanj v bližini, potreboval bi pripomočke, ki jih nimam (računalnik itd.));

Pomanjkanje podpore (delodajalec me ne bi podprl, družina me ne bi podprla);

Pomanjkanje zaupanja v lastne sposobnosti (ne bi rad, da bi ljudje izvedeli v kolikor bi bil neuspešen, nimam potrebne kvalifikacije, da bi lahko študiral to kar me zanima, ne vem v čem bi se lahko izobraževal, da bi bilo zanimivo in uporabno).

Malhotra in Shapero (2007) sta v raziskavo vključila potencialne udeležence izobraževanj in na tej osnovi oblikovala model s 6 skupinami ovir:

Slabe izkušnje (nizke ocene in ne prepričanje o mojih sposobnostih, ne uživam v učenju, bojim se, da sem prestar za učenje, utrujen, da bi šel v šolo in razred, ne izpolnjujem pogojev za vpis na program);

Institucionalne ovire (nimam prevoza, prijateljem ali družini ni všeč ta ideja, preveč birokracije za izvedbo vpisnega postopka, nimam prostora kjer bi se lahko učil ali vadil, bojim se izpasti preveč ambiciozen);

Pomanjkanje časa in energije (pomanjkanje časa, delovne obveznosti, družinske obveznosti, pomanjkanje energije ali vztrajnosti)

Ponudba izobraževanj (izobraževanja, ki me zanimajo niso na voljo, izobraževanje ni predvideno, ko se ga lahko udeležim, pomanjkanje informacij o krajih in ljudeh, ki ponujajo to kar me zanima),

Razmerje med stroški in koristmi (potrebna prisotnost na izobraževanjih, vprašanje financiranja, nimam izobraževalnih ciljev ali usmeritve);

Družinske obveznosti (varstvo otrok, cena knjig in šolnina, študijsko gradivo, težave s prevozom).

Kot je razvidno iz gornjih modelov, so avtorji oblikovali različne skupine ovir, pri čemer so določene posamezne ovire tudi različno razvrščene po skupinah. O težavah in omejitvah pri umestitvi so pisali že Roosmaa in Saar (2011) in Radovan (2012b), ki so opozorili, da določene ovire, npr. varstvo otrok in finančne ter logistične težave (pa tudi druge), lahko uvrstimo tako med situacijske kot institucionalne ovire. Njihova umestitev je odvisna od izvora problema. Radovan (2012b) navaja kot omejitev tudi nezavedne dejavnike, ki vplivajo na posameznika in njegove odločitve, a jih posameznik ne navaja kot ovire. Hkrati opozori tudi, da kvantitativne raziskave kažejo, da 
so najbolj izpostavljene situacijske in institucionalne ovire, dispozicijske pa so manj izražene.

Zaradi težnje po globljem razumevanju in natančnejšem odkrivanju ovir pri posameznikih, so nekateri raziskovalci (Beder, 1990; Hayes, 1988; Quigley, 1997) uporabili kvalitativni pristop, kjer so rezultati prikazali dispozicijske ovire kot tiste ovire, ki najbolj izstopajo pri posameznikih. To potrjujejo tudi Rubenson in Desjarkins, (2009) ter Falasca (2011), ki ugotavljajo da sta glavni skupini ovir pri odločanju za izobraževanje situacijske in dispozicijske ovire.

V slovenskem izobraževalnem prostoru so bile na temo ovir opravljene nekatere raziskave, ki pa niso temeljile na ustrezno validiranih vprašalnikih. Tako je denimo Kranjčeva (1982) ugotovila, da odrasli kot ovire pri odločanju za izobraževanje najpogosteje izpostavljajo pomanjkanje časa in strah pred neuspehom. Pri objektivnih ovirah so anketiranci najpogosteje izpostavili pretežke pogoje za izobraževanje ter drag študij.

Mohorčič Špolar (1999) je izpostavila, da med ovirami prevladujejo situacijske, sledijo jim institucionalne in nato dispozicijske ovire. Najbolj pogosta ovira, zaradi katere se odrasli niso odločili za izobraževanje, je bila prevelika zaposlenost in s tem tudi pomanjkanje časa, sledilo je predrago izobraževanje in pomanjkanje denarja.

Nekoliko novejši raziskavi (Anketa o izobraževanju odraslih 2007, 2011) kažeta, da so najpogosteje izpostavljene situacijke ovire. Rezultati iz leta 2007 prikazujejo, da so bile najbolj izpostavljene naslednje ovire: izobraževanje se ni ujemalo z urnikom dela, izobraževanje je bilo predrago in posameznik si ga ni mogel privoščiti ter družinske obveznosti. Rezultati iz leta 2011 (STAT, 2012), pa kažejo, da je glavni razlog zakaj se odrasli ne odločajo za izobraževanje to, da izobraževanja ne potrebujejo. Kot pomembne ovire anketiranci izpostavljajo tudi družinske obveznosti. Predrago izobraževanje se je kot ovira izkazalo pri tistih, ki se niso želeli izobraževati, šele na petem mestu.

Vse štiri raziskave opravljene $\mathrm{v}$ našem prostoru tako izpostavljajo pomanjkanje časa in predrago izobraževanje kot občutno najpogostejši in najpomembnejši oviri v izobraževanju. Le pri raziskavi iz leta 2011 je na prvem mestu izpostavljena dispozicijska ovira izobraževanja ne potrebujejo.

\section{Namen raziskave}

Namen študije je bil konstruirati in validirati Lestvico ovir pri odločanju za izobraževanje, pri čemer smo na podlagi teoretskih in empiričnih izhodišč želeli oblikovati instrument, ki bi bil primeren za slovenski izobraževalni prostor.

\section{Metodologija}

\section{Vzorec}

$\mathrm{V}$ študiji je sodelovalo 158 odraslih, med katerimi jih je bilo $88(55,7 \%)$ ženskega spola in $70(44,3 \%)$ moškega spola. V raziskovalnem vzorcu prevladujejo odrasli stari med 16 in 30 let $(38,6 \%)$ oseb. Sledijo odrasli stari med 31 in 46 let $(30,4 \%)$, nato od 47 do 62 let $(16,5 \%)$, najmanj je 
vključenih odraslih starih nad 63 let, in sicer le 23 (14\%). Starost anketirancev smo kategorizirali v skladu z OECD kategorizacijo, ki vključuje $\mathrm{v}$ raziskave odrasle stare nad 16 let. $^{1}$

Vsebinske osnove lestvice

Vsebinsko osnovo Lestvice ovir pri odločanju za izobraževanje smo črpali iz različnih teoretičnih in empiričnih modelov (Johnstone in Rivera, 1965; Cross, 1981; Darkenwald in Merriam, 1982; Beder; 1990; Larso in Milana; 2006; Malhotra in Shapero; 2007) iz katerih smo oblikovali nabor trditev. Trditve so se nanašale na različne ovire pri odločanju za izobraževanje. Nekateri primeri postavk so »Slabi vtisi prejšnjega izobraževanja.«, »Stroški izobraževanja.«, »Pomanjkanje časa.«, »Oddaljenost od izobraževalne ustanove.«, »Neprimeren čas poteka izobraževanja.« in »Počutim se prestar/a.«

Anketiranci so pri vseh 14-ih ovirah s pomočjo petstopenjske ocenjevalne lestvice (kjer je 1 - pomenilo, da sploh ne vpliva pri odločanju za izobraževanje, 5 - pa, da zelo vpliva pri odločanju za izobraževanje) ocenjevali, kako pomembna se njim zdi ovira (samoocena anketiranca), glede na njihovo trenutno stanje, pri odločanju tako za neformalno kot formalno izobraževanje.

Obdelava podatkov

Za vsako izmed 14 trditev (postavk) ter za skupni dosežek lestvice smo najprej preverili osnovno opisno statistiko ter normalnost porazdelitve. Nadalje smo preverili povezanost vsake posamezne postavke s skupnim dosežkom. Na osnovi te analize in nizke interkorelacije med spremenljivkami smo iz vprašalnika izločili 1 postavko, tako, da končna oblika Lestvice ovir pri odločanju za izobraževanje vključuje 13 postavk. Zanesljivost lestvice smo preverjali $\mathrm{z}$ metodo notranje konsistentnosti (Cornbachovim $\alpha$ koeficientom) ter $\mathrm{z}$ izračunom koeficienta zanesljivosti (po načelu $\mathrm{r}_{\mathrm{tt}}=\sqrt{ } \mathrm{h}^{2}$ ). Veljavnost lestvice smo preverjali s pomočjo faktorske analize, pri čemer smo najprej uvedli Kaiser - Mayer - Olkinov ter Bartletov preizkus sferičnosti.

\section{Rezultati}

Osnovna deskriptivna statistika in normalnost porazdelitve

\begin{tabular}{llllllllll}
\hline $\begin{array}{l}\text { Post } \\
\text { avke }\end{array}$ & $\boldsymbol{M}$ & $\boldsymbol{S D}$ & min & max & $\boldsymbol{A s}$ & $\boldsymbol{S p l}$ & $\mathbf{K S}$ & $\boldsymbol{P}$ \\
\hline 1 & 151 & 2,56 & 1,364 & 1 & 5 &, 351 & $-1,084$ &, 191 & $* * *$ \\
\hline 2 & 149 & 4,13 & 1,123 & 1 & 5 & $-1,184,478$ &, 298 & $* * *$ \\
\hline 3 & 150 & 3,83 & 1,195 & 1 & 5 &,- 964 &, 131 &, 249 & $* * *$ \\
\hline 4 & 149 & 3,15 & 1,309 & 1 & 5 &,- 253 &,- 912 &, 185 & $* * *$ \\
\hline 5 & 149 & 3,44 & 1,301 & 1 & 5 &,- 446 &,- 889 &, 204 & $* * *$ \\
\hline 6 & 150 & 1,96 & 1,253 & 1 & 5 & 1,115 &, 127 &, 312 & $* * *$ \\
\hline 7 & 150 & 3,09 & 1,331 & 1 & 5 &,- 057 &,- 985 &, 179 & $* * *$ \\
\hline 8 & 149 & 3,11 & 1,351 & 1 & 5 &,- 248 & $-1,105$ &, 145 & $* * *$ \\
\hline
\end{tabular}

\footnotetext{
${ }^{1}$ Pri starostnem razponu anketirancev smo sledili praksi PIAAC raziskave (OEDC, 2016).
} 


\begin{tabular}{llllllllll}
\hline 9 & 150 & 1,93 & 1,139 & 1 & 5 & 1,071 &, 271 &, 188 & $* * *$ \\
\hline 10 & 149 & 3,05 & 1,469 & 1 & 5 &,- 146 & $-1,334$ &, 287 & $* * *$ \\
\hline 11 & 147 & 2,84 & 1,335 & 1 & 5 &, 094 & $-1,058$ &, 170 & $* * *$ \\
\hline 12 & 150 & 2,08 & 1,240 & 1 & 5 &, 874 &,- 439 &, 161 & $* * *$ \\
\hline 13 & 146 & 2,17 & 1,366 & 1 & 5 &, 853 &,- 535 &, 261 & $* * *$ \\
\hline OVI & 152 & 36,6382 & 10,03804 & 2,00 & 60,00 &,- 331 &, 564 &, 080 & $N p$ \\
\hline
\end{tabular}

$N$ - numerus; $M$ - aritmetična sredina; $S D$ - standardna deviacija, Min/max - najnižja in najvišja vrednost; As - asimetričnost; Spl - sploščenost; KS Kolmogorov-Smirnov koeficient; *** - koeficient KS je statistično pomemben na nivoju $p<0.000 ; n p$ - koeficient KS statistično ni pomemben; OVI skupna povprečna vsota vrednosti postavk na lestvici OVI;

Preglednica 1: Osnovna deskriptivna statstika in normalnost prazdelitve posameznih postavk in celotne lestivce OVI

Iz Preglednice 1 lahko razberemo opisno statistiko posameznih postavk in povprečne skupne vrednosti vzorca. Kažeta se dve značilnosti. Vrednosti posameznih postavk se porazdeljujejo nenormalno, pri čemer menimo, da so dobljeni rezultati pričakovani saj zaradi specifičnosti vsake izmed postavk, ne bi mogli pričakovati normalne porazdelitve odgovorov anketirancev. Nasprotno, pa skupni povprečni rezultat kaže na normalno porazdelitev skupne povprečne mere, kar smiselno potrjuje ustreznost merskega instrumenta, ki preko obstoječih postavk zajame različna prepričanja glede ovir.

Veljavnost

Za preverjanje konstruktne veljavnosti lestvice smo uporabili faktorsko analizo. Kot priporoča Field (2005), smo najprej uvedli Kaiser - Mayer Olkinov preizkus ustreznosti vzorčenja ter Bartletov preizkus sferičnosti. Kaiser - Mayer - Olkinov preizkus $(\mathrm{KMO}=0,741)$ je bil višji od priporočene vrednost $\mathrm{KMO}=0,6$, kar potrjuje ustreznost vzorčenja. Bartletov preizkus $\left(\chi^{2}\right.$ $=508,293, \mathrm{df}=78, \mathrm{P}=0,000)$ pa je pokazal, da matrika ni identična in so podatki primerni za faktorsko analizo. $Z$ namenom ekstrakcije faktorjev smo uporabili metodo glavnih komponent s Promax rotacijo. Po kriteriju izločanja faktorjev z lastno vrednostjo nad 1 so bili dobljeni 3 faktorji (glej Preglednica 2), ki so skupaj pojasnili 52,5\% variance. Iz Preglednice 2 je razvidno, da v strukturi prevladuje en močan faktor, ki sam pojasni $31,81 \%$ variance in dva manjša faktorja, ki pojasnita preostali del variance. Glede na to, da prvi faktor pojasni več kot $20 \%$ variance (Field 2005), lahko trdimo, da je Lestvica ovir pri odločanju za izobraževanje veljavna. V nadaljevanju v Preglednici 2 in Preglednici 3 predstavljamo rezultate faktorske analize $\mathrm{z}$ metodo glavnih komponent, kjer je razvidno število dobljenih faktorjev ter struktura vsakega izmed njih (nasičenost faktorja s postavkami). 


\begin{tabular}{llll}
\hline Faktor & Lastna vrednost & $\begin{array}{l}\% \text { pojasnjene } \\
\text { variance }\end{array}$ & $\begin{array}{l}\text { Kumulativni } \% \\
\text { pojasnjene variance }\end{array}$ \\
\hline 1 & 4,135 & 31,807 & 31,807 \\
\hline 2 & 1,558 & 11,986 & 43,793 \\
\hline 3 & 1,127 & 8,669 & 52,462 \\
\hline
\end{tabular}

Preglednica 2 : Izločanje glavnih komponent.

\begin{tabular}{|c|c|c|c|}
\hline Postavka & $\mathrm{F}_{1}$ & $\mathrm{~F}_{2}$ & $\mathrm{~F}_{3}$ \\
\hline Neprimeren čas poteka izobraževanja. &, 835 & & \\
\hline Oddaljenost od izobraževalne ustanove. & 828 & & \\
\hline Neustrezen urnik predavanj. & ,733 & & \\
\hline Pomanjkanje časa. & ,670 & & \\
\hline Neustrezna ponudba izobraževanja v bližini. & ,638 & & \\
\hline Jezikovni in zdravstveni razlogi. & & ,729 & \\
\hline Ni interesa in želje po izobraževanju. & & ,688 & \\
\hline Družinske obveznosti & & ,642 & \\
\hline Počutim se prestar/a. & & 607 & \\
\hline Strah pred izpiti. & &, 564 & \\
\hline $\begin{array}{l}\text { Slaba informiranost } \\
\text { izobraževanja. }\end{array}$ & & & ,663 \\
\hline Slabi vtisi prejšnjega izobraževanja. & & & 655 \\
\hline Stroški izobraževanja. & & & 652 \\
\hline
\end{tabular}

\section{Preglednica 3: Nasičenost posameznih faktorjev}

Faktor 1 nasičuje 5 postavk, in sicer v razponu od 0,835 (Neprimeren čas poteka izobraževanja.) do 0,638 (Neustrezna ponudba izobraževanja $\mathrm{v}$ bližini.). Postavke skupaj pojasnjujejo $31,81 \%$ variance. Večinoma se povezujejo s časovnimi in logističnimi ovirami, zato smo faktor poimenovali Časovno logistične ovire. Faktor 1 torej sestavljajo poleg pomanjkanje časa vse tiste ovire, na katere posredno vpliva čas, tj. neprimeren časa poteka izobraževanja, oddaljenost od izobraževalne ustanove, neustrezen urnik predavanj, neustrezna ponudba izobraževanja $\mathrm{v}$ bližini in se kažejo kot logistične ovire. V kolikor dobljeni faktor primerjamo s faktorji predhodnih raziskav, opazimo, da se faktor 1 vsebinsko povezuje predvsem $\mathrm{s}$ kategorijama Pomanjkanje časa in/ali energije in Pomanjkanje razpoložljivih izobraževanj klasifikacije Larson in Milana (2006). Podobnosti med kategorijami srečamo tudi pri kvalifikaciji Malhotra in Shapero (2007), saj tudi njuna klasifikacija vključuje faktor Pomanjkanje časa in energije, kjer je tudi kakor pri Larson in Milana (2006) vključena ovira družinske obveznosti. V klasifikaciji Bedra (1990) ni faktorja, ki bi bil sličen dobljenemu faktorju Časovno logistične ovire. Najbolj se mu približuje kategorija Situacijske ovire. 
Faktor 2 nasičuje 5 postavk z utežmi od 0,729 (Jezikovni in zdravstveni razlogi.) do 0,564 (Slaba informiranost o možnostih izobraževanja.), ki skupaj pojasnjujejo $11,99 \%$ variance. Glede na to, da se postavke navezujejo na ovire, ki izhajajo iz posameznika, bi ta faktor lahko poimenovali Personalne ovire. Ta faktor se najbolj približuje Crossovi (1981) delitvi ovir, in sicer dispozicijskim oviram, čeprav faktor dobljen v pričujoči raziskavi vključuje tudi situacijski oviri Jezikovni in zdravstveni razlogi ter Družinske obveznosti. Podobnosti faktorja 2 srečamo tudi pri drugi kategoriji Negativna stališča ponovnega vstopa $\mathrm{v}$ izobraževanje klasifikacije Larson in Milana (2006) in prvi kategoriji Slabe izkušnje Malhotra in Shapero (2007), čeprav se tudi tukaj kažejo odstopanja, kot je npr. ovira družinske obveznosti, ki je v našem faktorju vključena.

Faktor 3 nasičujejo tri spremenljivke: Slaba informiranost o možnostih izobraževanja, Slabi vtisi prejšnjega izobraževanja, in Stroški izobraževanja, z utežmi od 0,663 do 0,652, ki skupno pojasnjujejo 8,67 \% variance, glede na vsebino trditev smo ga po zgledu Bederja (1990) poimenovali Doživljanje lastnega napora.

Celotna klasifikacija in porazdelitev ovir med faktorji kaže na to, da je ta glede na kategorije najbolj podobna klasifikaciji Larson in Milana (2006). Kategorijo Časovne in logistične ovire lahko povežemo s kategorijama Pomanjkanje časa in/ali energije in Pomanjkanje razpoložljivih izobraževanj. Kategorijo 2 lahko povežemo s faktorjem Pomanjkanje zaupanja v lastne sposobnosti. Kategorijo 3 pa $\mathrm{s}$ faktorjem Negativna stališča ponovnega vstopa v izobraževanje. Kategorizacija Larson in Milana (2006) sicer vsebuje še kategorijo Pomanjkanje podpore, ki pa je bila v pričujoči raziskavi zaradi nizke interkorelacije izločena iz nadaljnje obdelave.

Opravljena primerjava je pokazala, da se med raziskavami kategorij kažejo predvsem povezanosti med ovirami znotraj kategorij. Najbolj očitna je povezanost časa in obveznosti tako družinskih kot službenih pri ostalih prej omenjenih raziskavah. Naša klasifikacija kaže povezanost s časom na podoben način, vendar nekoliko bolj logistično usmerjen. Kategorija Časovna in logistična ovira prikazuje kako se čas najbolj povezuje z urnikom izobraževanja in oddaljenostjo od kraja izobraževanja, torej na tiste ovire, ki vplivajo na razpoložljiv čas posameznika. Kategorijo časovne in logistične ovire ocenjujemo kot kategorijo z največ podobnostmi v primerjavi z ostalimi raziskavi. V drugi kategoriji smo pridobili Personalne ovire, ki se nanašajo predvsem na posameznikova notranja stališča in občutke, s katerimi se posameznik srečuje pri odločanju za izobraževanje. Kot tretjo, najmanjšo kategorijo oblikujejo tri ovire, ki morda ne delujejo povezano, vendar bi lahko sklepali, da se posamezniki s slabimi predhodnimi izkušnjami manj zanimajo za izobraževanje (in tako menijo, da so slabo informirani) ter posledično doživljajo izobraževanje kot dodaten strošek. Kategorija Doživljanje lastnega napora se vsebinsko najbolj povezuje $\mathrm{z}$ isto imenovano kategorijo po Bederju (1990).

Opisane faktorje $\mathrm{v}$ nadaljevanju imenujemo komponente Lestvice ovir pri odločanju za izobraževanje. 


\begin{tabular}{llllll}
\hline Kompnenta & M & SD & \multicolumn{3}{l}{ Korelacija } \\
\cline { 3 - 6 } & & & 1 & 2 & 3 \\
\hline 1 & 3,31 & 0,98 & 1.000 & $0,399 * *$ & $0,440 * *$ \\
\hline 2 & 2,22 & 0,85 & & 1.000 & $0,343^{* *}$ \\
\hline 3 & 3,10 & 0,95 & & & 1.000 \\
\hline
\end{tabular}

**Korelacija je statistično značilna na nivoju $P<0,01$; * korelacija je statistično značilna na nivoju $P<0,05$.

Preglednica 4: Deskriptivna statistika za komponente ter korelacija med komponentami

Za vsako izmed dobljenih komponent smo preverili tudi deskriptivno statistiko in povezanost med komponentami. Najvišje povprečje je bilo ugotovljeno pri komponenti 1 - Časovno logistične ovire $(\mathrm{M}=3,31, \mathrm{SD}=$ $0,98)$, Sledi komponenta Doživljanje lastnega napora $(\mathrm{M}=3,10, \mathrm{SD}=0,95)$. Najnižje povprečje je bilo izračunano za komponento 2 - Personalne ovire $(\mathrm{M}=2,22, \mathrm{SD}=0,85)$. Korelacijski koeficienti kažejo, da obstaja pozitivna in statistično značilna povezanost med vsemi tremi komponentami. Najvišjo povezanost kažeta komponenti Časovno logistične ovire in Doživljanje lastnega napora $(\mathrm{r}=0,440, \mathrm{P}<0.05)$, najnižje pa komponenti Personalne ovire in Doživljanje lastnega napora $(\mathrm{r}=0,343, \mathrm{P}<0,05)$.

Zanesljivost

\begin{tabular}{lllll}
\hline Komponenta & $\mathrm{K}_{1}$ & $\mathrm{~K}_{2}$ & $\mathrm{~K}_{3}$ & $\mathrm{OVI}^{*}$ \\
\hline $\begin{array}{l}\text { Stevilo } \\
\text { postavk }\end{array}$ & 5 & 5 & 3 & 13 \\
\hline Cronbachov & 0,820 & 0,802 & 0,785 & 0,813
\end{tabular}

Alfa

K-komponenta, * Vsota posamičnih postavk.

Preglednica 5: Cronbachov alfa koeficient za posamezne komponente ter za lestvico kot celoto

Cronbachov alfa koeficient $(\alpha=0,813)$ lestvice ovir pri odločanju za izobraževanje kaže, da je lestvica zanesljiva. Analiza zanesljivosti posameznih komponent pa pokaže visoko zanesljivost komponent Časovno logistične ovire $\left(\mathrm{K}_{1}\right)(\alpha=0,820)$ in Personalne ovire $\left(\mathrm{P}_{2}\right)(\alpha=0,802)$ ter nekoliko nižjo, a še vedno dovolj visoko zanesljivost komponente Doživljanje lastnega napora $\left(\mathrm{K}_{3}\right)(\alpha=0,785)$. Izračun koeficienta zanesljivosti $\left(\mathrm{r}_{\mathrm{tt}}\right)$ pa kaže, da je spodnja meja zanesljivosti lestvice 0,725 .

\section{Zaključek}

Cilj predstavljene študije je bil konstruirati in validirati lestvico ovir pri odločanju za izobraževanje. Končna verzija lestvice vključuje 13 postavk, ki smo jih na osnovi rezultatov faktorske analize oblikovali v 3 komponente: (i) Časovno logistične ovire (ii) Personalne ovire in (iii) Doživljanje lastnega napora. Prvi faktor pojasnjuje 31,81\% variance, vsi trije dobljeni faktorji pa $52,64 \%$. Zanesljivost posameznih komponent se giblje med 0, 785 in 0, 820, ter 0,813 za celotno lestvico. Rezultati kažejo, da smo oblikovali zanesljiv 
( $\alpha=0,813)$ in veljaven instrument, ki omogoča metodološko ustrezno podprto raziskovanje ovir pri vključevanju odraslih v izobraževanje.

V možnostih za nadalje raziskovanje bi bilo smiselno lestvico preveriti na eni strani na večjem vzorcu, na drugi strani pa na specifičnih bolj definiranih vzorcih (npr. odrasli z nedokončano osnovno šolo, odrasli z zaključeno srednjo šolo, odrasli z visokošolsko izobrazbo, odraslimi iz depriviligiranih okolij ipd.).

\section{Bibliographic references}

BEDER, H. 1990. Reasons for nonparticipation in adult basic education. Adult Education Quarterly, vol. 40, n. 4, pp. 207-218.

CROSS, K. P. 1981. Adults al Learners: Increasing Participation and Facilitating Learning. San Francisco: Jossey-Bass Publishers.

EUROPEAN COMMISSION. 2005. Task force report on adult education survey. Luxembourg: Office of Official Publications of the European Communities. Available online: http://ec.europa.eu/eurostat/documents/3888793/5833561/KS-CC-05-005-

EN.PDF/7175b7bb-2102-4204-a83c-f51d5d9b7532.

DARKENWALD, G. - MERRIAM, S. 1982. Adult education: Foundations of practice. New York: Harper and Row.

FALASCA, M. 2011. Barriers to adult learning: Bridging the gap. Australian Journal of Adult Learning, vol. 51, n. 3, pp. 583-590.

FIELD, A. 2005. Discovering statistics using SPSS. London: Sage Publications.

FRIEBE, J. - SCHMIDT-HERTHA, B. 2013. Activities and barriers to education for elderly people. Journal of contemporary educational studies, vol. 64, n. 1, pp. 10-18.

HAYES, E. R. 1988. A typology of low-literate adults based on perceptions of deterrents to participation in adult basic education. Adult Education Quarterly, vol. 39, n. 1, pp. 1-10.

KRAJNC, A. 1982. Motivacija za izobrazevanje. Ljubljana: Delavska enotnost.

LARSON, A. - MILANA, M. 2006. Barries towards participation in adult education and training. University of Geneva, European Conference on Educational Research. Available online: www.leeds.ac.uk/educol/documents/157725.htm.

MALHOTRA, N. K. - SHAPERO, M. 2007. Factor structure of deterrents to adult participation in higher education. Journal of college theaching \& learning, vol. 12, n. 4, pp. 81-90.

MCGIVNEY, V. 1990. Access to education for non-participant adults. Leicester: National Institute of Adult Continuing Education.

MOHORCIC SPOLAR, V. 1999. Mednarodna raziskava pismenosti odraslih. Tehnično poročilo. Available online: http://arhiv.acs.si/skenirana\%20porocila/1999/ALS\%20tehnicno\%20porocilo .pdf.

OECD. 2016. Raziskava spretnosti odraslih PIAAC v Sloveniji 2016. Available online: https://www.oecd.org/skills/piaac/Skills-Matter-SloveniaSlovenian-Version.pdf. 
QUIGLEY, A. B. 1997. Rethinking literacy education: The critical need for practice-based change. San Francisco: Jossey-Bass.

RADOVAN, M. 2012a. Izobrazevalne ovire. V Javrh, P. in Kuran, M. (ur.), Temeljne zmožnosti odraslih (pp. 136-146). Ljubljana: Andragoski center Slovenije.

RADOVAN, M. 2012b. Razumevanje izobraževalnih ovir z vidika modela omejenega delovanja. Sodobna pedagogika, vol. 70, n. 2, pp. 70-88.

ROOSMAA, E. - SAAR, E. 2011. Barriers to and in participation in lifelong learning. Country report on Estonia. Tallinn: Tallinn university, Institute of International and Social Studies. Available online: http://1112010.tlu.ee/folder.2006-02-22.7534376022/subproject-2/sp2-

national-reports/sp2_nr_estonia_b-3.pdf.

RUBENSON, K. - DESJARDINS, R. 2009. The Impact of welfare state regimes on barriers to participation in adult education: A bounded agency model. Adult Education Quarterly, vol. 59, n. 3, pp. 187-207.

STAT. 2010. Izobrazevanje odraslih (po anketi o izobrazevanju odraslih). Statisticne informacije, $3 . \quad$ Available online: https://www.stat.si/doc/statinf/09-si-272-1001.pdf.

STAT. 2012. Anketa o izobrazevanju odraslih, 2011. Available online http://www.stat.si/StatWeb/glavnanavigacija/podatki/prikazistaronovico?IdN ovice $=4896$.

asist. Nina Krmac, $\mathrm{PhD}$

Department of Educational Sciences

University of Primorska

Faculty of Education

Cankarjeva 5

6000 Koper

Slovenia

nina.krmac@pef.upr.si

asist. prof. Tina Štemberger, PhD

Department of Educational Sciences

University of Primorska

Faculty of Education

Cankarjeva 5

6000 Koper

Slovenia

tina.stemberger@pef.upr.si 